by Jin Yugan, Bruce R. Wardlaw, Brian F. Glenister and Galina V. Kotlyar

\title{
Permian chronostratigraphic subdivisions
}

\begin{abstract}
Names and boundary levels for series and stages of the Permian System, based on marine successions, have been approved by the Permian Subcommission, ICS. These are the Cisuralian, Guadalupian, and Lopingian Series and their constituent stages standardized respectively in the Urals, Southwest USA, and South China for the Lower, Middle, and Upper Permian.
\end{abstract}

\section{Historic review}

The Permian System was proposed by Murchison in 1841 for sedimentologically diverse deposits in the Ural Mountains of Russia. Equivalents had been recognised previously in western Europe as the Dyas or other rock units, but could not be defined satisfactorily as a System because of the paucity of fossil content. The classic Permian succession was extended downward by Karpinsky (1874) and subsequently by Ruzhencev (1936), and became firmly established through extensive twentieth century investigations. Dunbar (1940) provided an excellent review of classification and correlation of the Urals Permian, contributing to its wide acceptance as the international standard (Figure 1).

Problems arose because the depositional sequence in the Urals above the Artinskian is dominated by non-marine sediments, and is thus inadequate for definition of post-Artinskian chronostratigraphic subdivisions. However, post-Artinskian chronostratigraphy can be defined precisely in a number of paleoequatorial marine sequences. Glenister and Furnish (1961) attempted to provide an integrated scheme of marine sequences with substitutions for the traditional Upper Permian Urals standards, and various composite schemes have been proposed subsequently (Stepanov, 1973; Furnish, 1973; Waterhouse, 1976; Kozur, 1977 ). None of these composite schemes has gained overwhelming acceptance, largely because they are composed of stages with reference areas distant from each other. This separation necessitates determination of stratigraphic superposition of neighbouring stages based on the interpreted evolutionary succession of regionally restricted ammonoid, brachiopod, and fusulinacean faunas, or on previously premature zonation of conodonts. It has therefore become apparent that an integrated standard succession should be simplified to comprise a minimum number of reference areas. The scheme consisting of Cisuralian, Guadalupian, and Lopingian Series and their constituent regional stages proposed by Waterhouse (1982) is a simplified integrated succession that was accepted subsequently in a global time scale (Harland et al., 1990).

Recent refinement of the zonation of Permian conodonts provides an excellent biostratigraphic basis for precise boundary correlation of type sections for the three series. The succession Asselian, Sakmarian, and Artinskian was further documented as a potentially qualified international standard, in connection with the 1991 International Congress on the Permian System of the World (Chuvashov and Nairn, 1993) and the Guadalupian Series of North America also was formally proposed there as a global standard (Glenister et al., 1992). More recently, the faunal successions of the Lopingian Series in South China have been further documented (Jin et al., 1993; Mei et al., 1994b). With support from the updated zonation of conodonts, ammonoids, and fusulinaceans, an operational scheme incorporating these three most promising reference successions was proposed (Jin et al., 1994a; 1994b) as a working template for the Subcommission on Permian Stratigraphy (SPS). However, the Chihsian/Cathedralian Series in the proposed scheme met with reservations, due to uncertainty of correlation between Tethyan and North American successions. SPS meetings early in 1996 suggested the compromise of retaining the name of the Kungurian Stage, but designating the body

\begin{tabular}{|c|c|c|c|c|c|c|c|c|c|c|c|c|c|}
\hline \multicolumn{4}{|c|}{ Permian Subcommission, 1996} & \multirow{2}{*}{\multicolumn{2}{|c|}{$\begin{array}{l}\text { Glenister \& } \\
\text { Funish, } 1961\end{array}$}} & \multirow{2}{*}{\multicolumn{2}{|c|}{ Furnish, 1973}} & \multirow{2}{*}{\multicolumn{2}{|c|}{ Waterhouse, 1982}} & \multirow{2}{*}{\multicolumn{2}{|c|}{ Harkand et ol., 1990}} & \multirow{2}{*}{\multicolumn{2}{|c|}{ Jin et al., 1994}} \\
\hline \multicolumn{2}{|c|}{ Series } & Stages & Basal conodont zone & & & & & & & & & & \\
\hline & \multirow{3}{*}{ | } & Changhsingian & Clankina subcarinata & \multirow{3}{*}{ 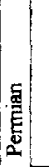 } & \multirow{3}{*}{ Dzhulian } & \multirow{3}{*}{ 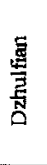 } & Changhsingian & \multirow{3}{*}{$\begin{array}{l}\frac{5}{6} \\
\frac{5}{5} \\
\frac{5}{3} \\
-1\end{array}$} & Charghasingian & \multirow{3}{*}{ 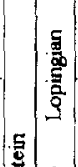 } & \multirow{3}{*}{ Changhsingian } & \multirow{3}{*}{ 急 } & Changhsingian \\
\hline & & & & & & & Chlidruan & & I unmtonim 50 & & & & Dzhulfian \\
\hline & & Wuchiapingian & Clarkina postbitteri & & & & Araksian & & Lurgignian & & & & (Wuchiapingian) \\
\hline \multirow{3}{*}{\multicolumn{2}{|c|}{ 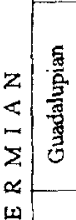 }} & Capitanian & Sinopondolella postaserrata & \multirow{3}{*}{ 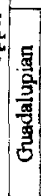 } & Capitanian & \multirow{2}{*}{ 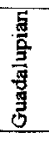 } & Amarassian & \multirow{4}{*}{$\frac{5}{5}$} & Capitanian & & Capitanian & \multirow{3}{*}{$\begin{array}{l}\frac{5}{2} \\
\frac{3}{3} \\
\frac{3}{9} \\
5\end{array}$} & Capitanian \\
\hline & & Wordian & & & \multirow{2}{*}{ Wordian } & & Wordian & & & & Wordian & & Wordian \\
\hline & & & Sinogondolella nankingensis & & & \multirow{3}{*}{$\begin{array}{l}\frac{9}{9} \\
\frac{9}{4} \\
\frac{5}{4}\end{array}$} & Roadian & & & & Ufimian & & Roadian \\
\hline $\begin{array}{l}\infty \\
\infty \\
2\end{array}$ & \multirow{5}{*}{ 总 } & Kungurian & $\begin{array}{l}\text { Neostreptognathodus pnevi- } \\
\text { N. exculptus }\end{array}$ & \multirow{2}{*}{ 变 } & Baigendzhinian & & Leonardian & & Roadian & \multirow{5}{*}{ 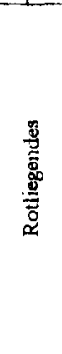 } & Kungurian & ह & $\begin{array}{l}\text { Kubergandinian } \\
\text { Bolorian }\end{array}$ \\
\hline & & Artinskian & $\begin{array}{l}\text { Sweetognathus whiter- } \\
\text { Mesagondolella bisselli }\end{array}$ & & Aktastinian & & Aktastinian & \multirow{4}{*}{ 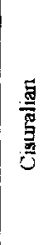 } & Baigendzinian & & Artinskian & \multirow{4}{*}{ 苞 } & Artinskian \\
\hline & & & & 5 & & \multirow{3}{*}{ 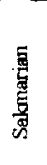 } & Sterlitamakian & & & & & & \\
\hline & & Sakmarian & Streptognathodus postfusus & है। & Sakmarian & & Tastubian & & Sakmarian & & Salonarian & & Saltnanan \\
\hline & & Asseljan & Streprognathodus isolatus & & Asselian & & Asselian & & Asselian & & Asselian & & Asselian \\
\hline
\end{tabular}

Figure 1 Development of Permian chronostratigraphic scales. This chart is designed to show the succession of chronostratigraphic units in selected scales rather than the correlation between them. 


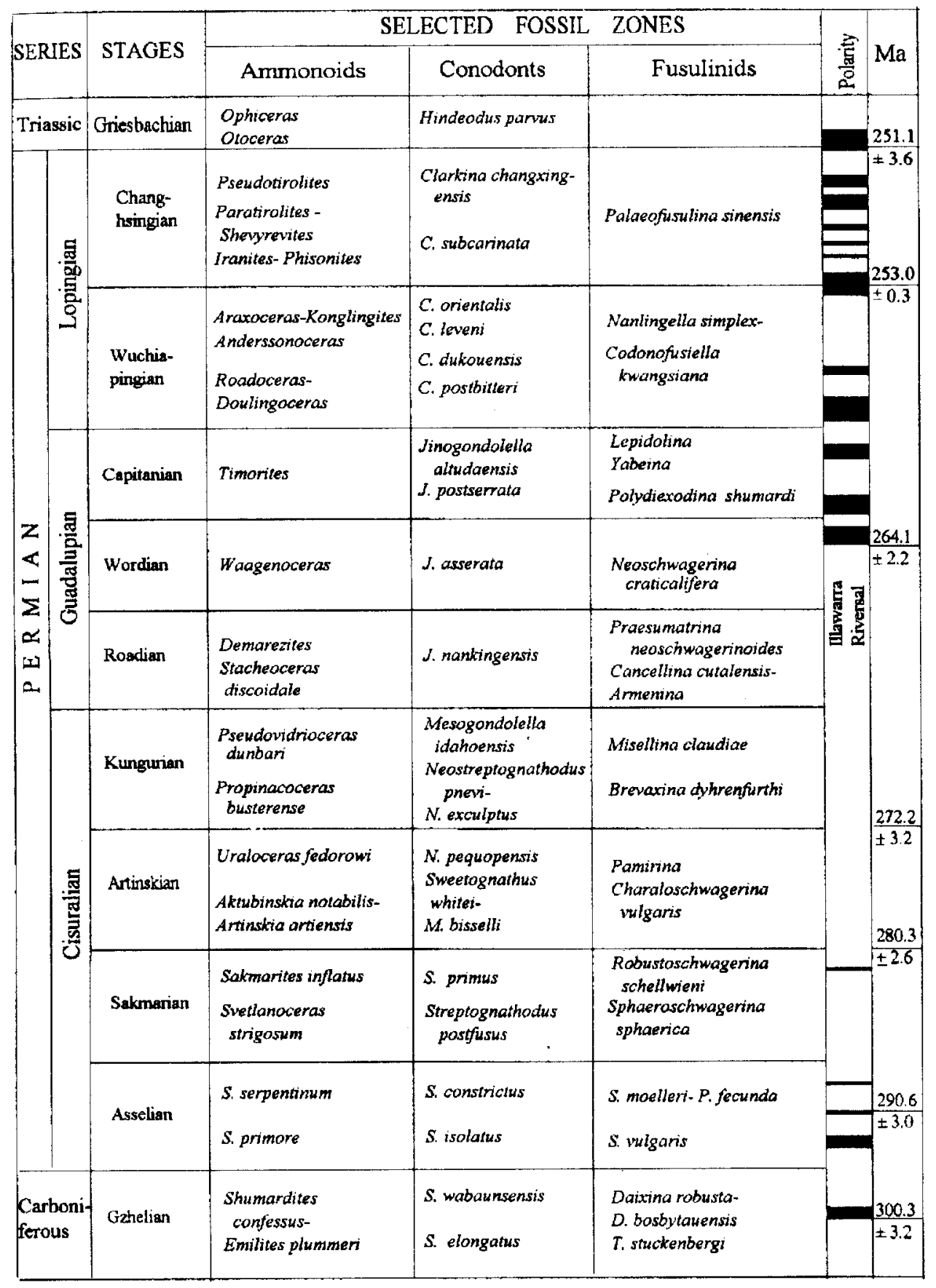

Figure 2 An integrated chronostratigraphic scheme for the Permian System.

The stratigraphic ranges of fossils zones reflect a general version of respective series and stages but are mainly determined based on zonation in their eponymous regions. However, the Kungurian and Guadalupian fossil zones combine the conodont zones and ammonoid assemblages of Southwestern USA with the fusulinid zones of South China. stratotype in a paleoequatorial region that contains the open marine communities that are largely absent from the eponymous area (Jin, 1996). In July 1996, usage of Cisuralian, Guadalupian, and Lopingian and correlation of their constituent stages by reference to all eponymous areas, except that for the Kungurian Stage, were approved almost unanimously in a formal postal ballot of SPS Titular Members. Thus, the conclusion of the long journey to integrate suitable marine reference successions into a single Permian chronostratigraphic scheme is near.

\section{Chronostratigraphic subdivisions}

The basal boundary of the Permian System and of the coincident Asselian Stage has been officially ratified by the ICS, with the GSSP at Aidaralash Creek, northern Kazakhstan. It is defined by the first appearance of the conodont Streptognathodus isolatus slightly below the contact of the ammonoid genozones of ShumarditesVidrioceras below, and Svetlanoceras-Juresanites above, and corresponding approximately to the base of the fusulinacean Sphaeroschwagerina vulgaris-S. fusiformis Zone (Davydov et al., 1995).

For the upper boundary of the Permian System, both the original definition for the base of the Triassic, the Buntsandstein of Germany, and the top of the Permian in the Urals are non-marine, and therefore unsuitable for worldwide correlation. The functional definition for the base of the Triassic has therefore been the base of the ammonoid Otoceras Zone of the Himalayas (Griesbach, 1880). The first appearance of the conodont Hindeodus parvus has been proposed as a more widespread and precise basis for primary definition of this boundary level (Yin et al., 1988), and has found general acceptance. Responsibility for formalization of this definition and of the coincident top of the Permian System lies with the Subcommission on Triassic Stratigraphy. 


\section{Cisuralian Series}

The name Cisuralian was proposed by Waterhouse (1982) to comprise the Asselian, Sakmarian, and Artinskian Stages. In the present scheme, it also includes the Kungurian, and therefore corresponds to the Lower Permian of a Russian proposal (Licharew, 1966; Kotlyar and Stepanov, 1984) and to the Rotliegendes of Harland et al. (1990). The Uralian Series, named by de Lapparent in 1900 and interpreted by Gerasimov (1937) to include pre-Kungurian stages of the Lower Permian, was utilized by Jin et al. (1994a). However, it is a name that is confused by varied historic usage, and we suggest replacement with the Cisuralian Series.

The duration of the proposed Cisuralian Series is much greater therefore than the remaining two higher Permian series, and eustatic and biotic changes near the base of the Kungurian Stage are globally significant (Leven et al., 1996). Consequently, the Cisuralian may be further subdivided into two independent series, or two subseries, of which the upper one might be equivalent to the Chihsian/Cathedralian Series of the preceding scheme (Jin et al., 1994a).

Amongst the constituent post-Asselian Cisuralian stages, the Sakmarian was proposed by Ruzhencev $(1950,1951)$, based on the Kondurovka Section along the Karamuruntau Range of the Sakmara River Valley. In the absence of ammonoids, the lower boundary was defined at the base of the Karamurunsk Suite by fusulinaceans of the Pseudofusulina moelleri Zone and coincides with the Eoparafusulina Genozone. In reference to conodont zonation, it is placed at the base of the Streptognathodus postfusus (=S. barskovi) Zone, which is coincident with the base of the Shikhanskian Horizon. The stage is subdivided into lower (Tastubian) and upper (Sterlitamakian) substages, the boundary between them coinciding in the Southern Urals with the bases of the fusulinacean Pseudofusulina urdalensis Zone, the conodont Sweetognathus primus Zone, and the ammonoid Sakmarites inflatus Zone (Figure 2).

The Artinskian Stage was proposed by Karpinsky in 1874, with the sandstone of the Kashkabash Mountain on the right bank of the Ufa River near Arty Village as the stratotype for its upper part and with the Kondurovka Section for its lower part. Ruzhencev defined the lower part of the stage by reference to ammonoids from the Kondurovk Suite of the Sterlitamakian, but the lower boundary of the Artinskian is now placed above this interval (Chuvashov et al., 1993). It is defined primarily on occurrence of species of Pseudofusulina, as ammonoids of the upper Sakmarian (Sterlitamakian) and lower Artinskian are similar. We suggest redefinition of the base of the Artinskian, on conodonts, at the base of the Sweetognathus whitei Zone, that is the base of the Bursevsky Horizon.

The Kungurian Stage was restricted formerly to the Philipovian and Irenian horizons of the type area. However, Chuvashov (1994) proposed redefinition of the lower boundary at the base of the Sarginskian Horizon, originally included within the Artinskian Stage. This is a readily correlatable level, marked by the first appearances of the fusulinacean Parafusulina. In the present scheme, the base of the Neostreptognathodus pnevi Zone of the Saraninsk Horizon is selected for definition, as it represents the first significant evolutionary event following the introduction of $N$. pequopensis, which occurs below a major sequence boundary. The corresponding Tethyan conodont zone is characterized by the occurrence of $N$. exsculptus in the upper part of fusulinacean Pamirina Zone of South China (Zhu and Zhang, 1994), and in the basal part of the Cathedralian of North America.

Menning (1993) referred the Permian magnetostratigraphic chrones to two superchrones, the Carboniferous-Permian Reversed Superchrone (CPRS) and the Permian-Triassic Mixed Superchrone

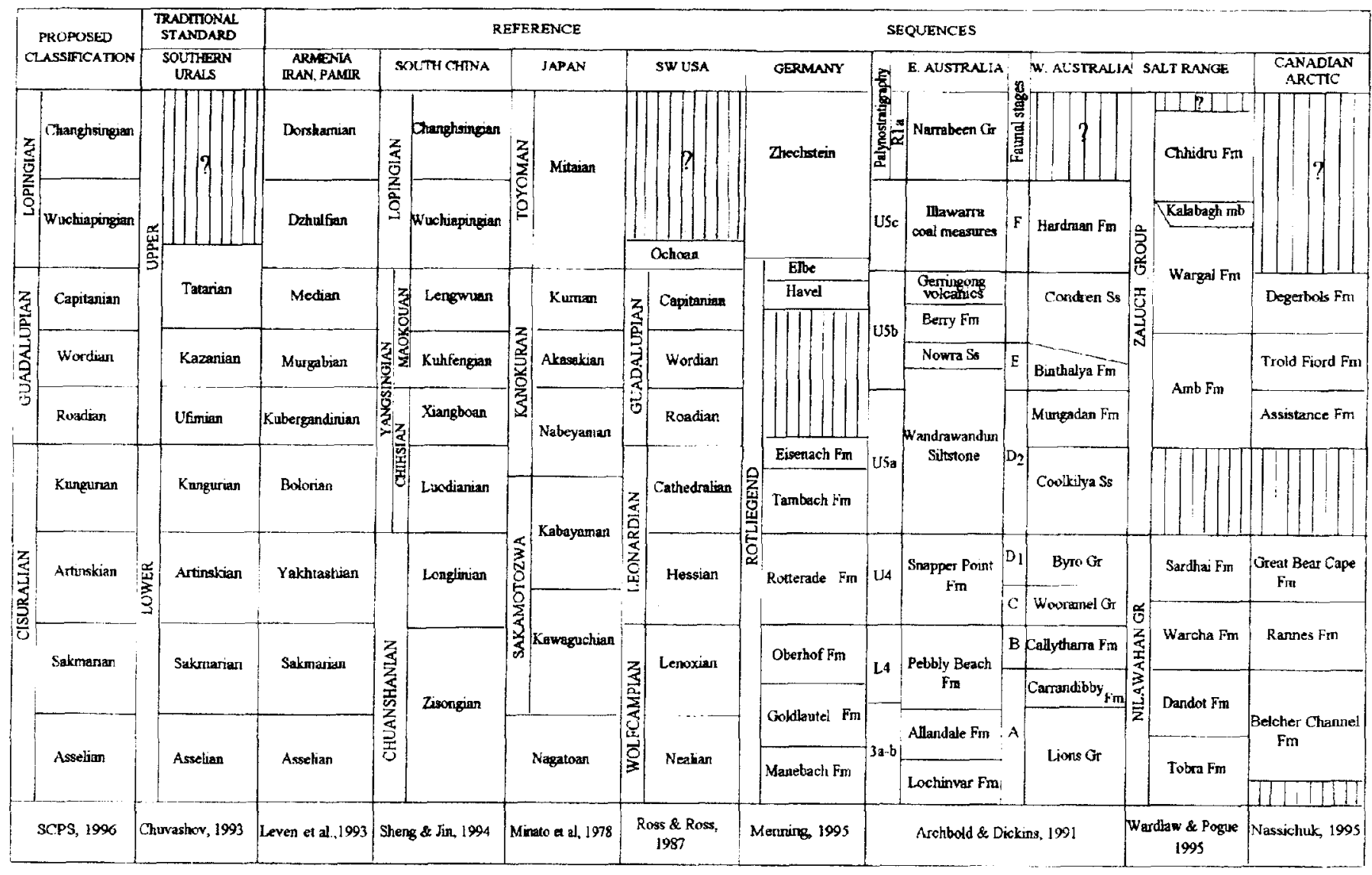

Figure 3 Correlation of selected Permian successions. The regional successions are adopted from the following authors' contributions: Germany from Menning (1995); Southwestern USA from Ross and Ross (1987); Western and Eastern Australia from Archbold and Dickins (1991); the Urals from Chuvashov (1993), the Salt Range from Wardlaw and Pogue (1995), the Kitakami Mts. of Japan from Minato et al. (1978) and the Arctic from Nassichuk(1995). 
(PTMS). He integrated five normal zones in the Permian part of the CPRS, as shown in the present Figure 2. However, the biostratigraphic control of the integration of three Asselian normal zones cannot be considered as robust. Moreover, no normal zone has been recognized from Asselian strata of the Southern Urals; instead, there are four normal zones from the uppermost Carboniferous (Davydov et al.. 1992).

Dating of samples from the Urals suggests that the age of the mid-Asselian is $290.6 \pm 3.0 \mathrm{Ma}$, and that the Sakmarian-Artinskian boundary is $280.3 \pm 2.6 \mathrm{Ma}$. Additionally, samples from the Branxton Formation of eastern Australia, considered early Kungurian, are dated as $272.2 \pm 3.2 \mathrm{Ma}$ (Roberts et al., 1996). Based upon the above data, the ages of the basal boundaries of the Asselian, Sakmarian, Artinskian and Kungurian stages are estimated respectively as 292 , 285,280 , and $272 \mathrm{Ma}$

\section{Guadalupian Series}

The base of the Guadalupian Series in West Texas is defined by the first appearance of Jinogondolella nankingensis within the evolutionary cline from Mesogondolella idahoensis to J. nankingensis displayed in the El Centro Member of the Cutoff Formation in Stratotype Canyon, Guadalupe Mountains (Glenister et al., 1992; Lambert and Wardlaw, 1996).

The Guadalupian comprises three stages, Roadian, Wordian, and Capitanian. The proposed boundary for the base of the Wordian Stage is the first appearance of Jinogondolella aserrata in the upper limestone beds of the Getaway Member of the Cherry Canyon Formation. This level is slightly higher than the first occurrence of the cyclolobid ammonoid Waagenoceras at the base of the Brushy Canyon Formation.

The Capitanian Stage could be defined by the first appearance of Jinogondolella postserrata in the upper part of the Pinery Limestone Member of the Bell Canyon Formation (Figure 1). This marks the first significant evolutionary event after the major sequence boundary that divides the Goat Seep from the Capitan reef (shelf) and the Cherry Canyon from the Bell Canyon Formation (slope and basin), and corresponds to the changeover from Parafusulina-dominated to Polydiexodina-dominated fusulinacean faunas and the occurrence of the ammonoid Timorites. Recent studies on the Guadalupian/Lopingian Series boundary have revealed an evolutionary lineage from Protoclarkina crofti to Clarkina postbitteri (Wardlaw and Mei, in press).

In its type locality in south China, Jinogondolella nankingensis was described from the Kuhfeng Formation of Wordian age, occurring with the cyclolobid ammonoid Shengoceras (subjective senior synonym of Kufengoceras); its lowest occurrence is the Praesumatrina neoschwagerinoides-Neoschwagerina simplex Zone, a level corresponding to the base of the Murgabian Stage. The stratigraphic range of the Roadian ammonoid fauna in Central Asia needs clarification, as it has been referred to the Kubergandinian (Bogoslovskaya and Leonova, 1994) as well as the $N$. simplex Zone, the latter generally regarded as basal Murgabian (Kotlyar and Pronina, 1995).

The sequence boundary just below the base of the Guadalupian Series appears to represent a global regression that corresponds to the base of the Ufimian Stage of the Urals. Similarly, the sequence boundary that separates the Cherry Canyon from the Bell Canyon Formation (Wordian/Capitanian) appears to be synchronous with the sequence boundary that marks the junction of the Kazanian and Tatarian Stages. Recognition of the Illawarra Magnetic Reversal near the base of the Capitanian and in the early part of the Tatarian Stage supports this apparent synchroneity.

Magnetostratigraphic sequences of the early Guadalupian represent the upper part of the Carboniferous-Permian Reversed Superchrone, whereas those of the upper Guadalupian belong in the Permian-Triassic Mixed Superchrone. The stratigraphic level of the Illawarra Reversal will eventually serve as a critical marker in global correlation, but to date has been recognized with precise biostratigraphic control in only two marine sections. It is located in the top part of the Maokou Formation in South China (Heller et al., 1995), and in the basal part of the Wargal Formation of the Salt Range (Haag and Heller, 1991), corresponding respectively to the Neoschwagerina margaritae Zone and the Jinogondolella aserrata Zone of the late Guadalupian. Menning has completed sampling to locate the Illawarra Reversal in the Guadalupian type area. Two and possibly three normal zones are present in the late Guadalupian.

The age of the Guadalupian basal boundary has been estimated as young as $256 \mathrm{Ma}$ by Harland et al. (1990) and $258 \mathrm{Ma}$ by Odin and Odin (1990). Recently Menning (1995) suggested the age to be $272 \mathrm{Ma}$. New age dates of zircons from a bentonite bed just below the suggested base for the Capitanian proposed stratotype (Wardlaw and Rohr, 1996) have yielded a reliable date of $264 \pm 2 \mathrm{Ma}$ (Bowling, personal communication, 1996). The estimates of Harland et al. (1990) and Odin and Odin (1990) are clearly in error. We suggest a more reliable estimation might be between the suggested age for the base of the Kungurian ( $272 \mathrm{Ma}$ ) and the newly established age for the top of the Wordian (264 Ma), approximately $269 \mathrm{Ma}$.

\section{Lopingian Series}

The Lopingian (Huang, 1932), Dzhulfian (Furnish, 1973), Transcaucasian and Yichangian (Waterhouse, 1982), as well as other references, have been proposed for the uppermost Permian series. Of these, the Lopingian appears to be the first formally designated series name to be based on a relatively complete marine sequence. Recent documentation of a comprehensive succession of conodont zones from the Capitanian through the Wuchiapingian Stage in the Lopingian of South China has greatly enhanced the qualifications of the Lopingian and its constituent stages as the international standard for the upper series of the Permian (Jin et al., 1993; Mei et al., 1994a, 1994b, 1994c). The base of the Clarkina postbitteri Zone represents the change from Jinogondolella-dominated faunas below to Clarkina-dominated faunas above, and therefore constitutes a most attractive level for the Guadalupian-Lopingian boundary (Jin et al, 1994c; Wardlaw and Mei, in press). This boundary is to be established within the top part Bed 19 in the Penglaitang section, Laibin County of Guangxi. The $C$. postbitteri conodont zone corresponds approximately to the ammonoid Roadoceras-Doulingoceras Zone (Zhou, 1987).

The Lopingian Series comprises two stages, Wuchiapingian and Changhsingian. Zhao et al. (1981) formally proposed the D Section in Meishan of Changxing County as the stratotype of the Changhsingian Stage. The lower boundary is located at the base of Bed 2 that separates the Clarkina orientalis Zone below from the Clarkina subcarinata Zone above. The basal part of this stage is also marked by the occurrence of the advanced forms of Palaeofusulina, and the ammonoid families Tapashanitidae and Pseudotirolitidae. The Dzhulfian and Dorashamian Stages of Transcaucasia correspond respectively to the Wuchiapingian and Changhsingian. However, the successions in the basal part of the Dzhulfian Stage and the top portion of the Dorashamian Stage are not as well developed in their type areas as corresponding intervals in the standard succession of South China (Iranian-Chinese Research Group, 1995).

The Tatarian of the traditional Urals standard corresponds to the uppermost Guadalupian and the Lower Lopingian, since the Illawarra Reversal appears in the basal part of both the Tatarian and the Capitanian (Menning, 1993). Lopingian marine deposits in Pangea are characterized by the occurrence of the Cyclolobus ammonoid fauna, as confirmed by associated Lopingian conodonts and foraminifers in the Salt Range (Wardlaw and Pogue, 1995).

The Lopingian part of the PTMS is based on data from South China and the Salt Range. A normal zone is recognised near the base of the Wuchiapingian, and another near the top (Heller et al., 1995). In addition, five distinct normal zones were reported from the Changhsingian strata in both the Meishan and Shangsi sections of South China (Li and Wang, 1989).

The age of Permian-Triassic boundary has been reported as $251.1 \pm 3.6 \mathrm{Ma}$ based on a SHRIMP zircon age of the boundary clay of the Meishan Section (Claoué Long et al., 1991), and as 249.9 (1.5 Ma based on ${ }^{40} \mathrm{Ar} /{ }^{29} \mathrm{Ar}$ dating of sanidine from the same horizon 
(Reno et al., 1995). Recent studies show that the age of the tuff beds at the base of the Changhsingian Stage in South China is around 253 Ma (Bowling, personal communication, 1997).

\section{Conclusions}

It has taken two decades for the Subcommission on Permian Stratigraphy to achieve agreement on the names and boundary levels of series and stage boundaries. Despite remaining minor differences of opinion, the proposed scheme enables the Subcommission to proceed with the selection of Global Stratotypes for intra-systemic boundaries. It permits correlation of Permian marine sequences, throughout the world, with higher resolution than achievable previously (Figure 3). However, proposed boundary levels will still be subject to change after further test of their correlation potential, which continues to constitute the basic strength of any general scheme.

\section{References}

Archbold, N W, and Dickins, J M, 1991, Australian Phanerozoic Timescales: 6. A standard for the Permian System in Australia: Bureau of Mineral Resources, Australian Record 1989/36, 17 pp.

Bogoslovskaya, M F, and Leonova, T B, 1994, Comments on the proposed operational scheme of Permian chronostratigraphy: Permophiles, no. 25, pp. 15-17.

Chuvashov, B I, 1994, Progress report of Permian Stratotypes Working Group: Permophiles, no. 25, pp. 7-8.

Chuvashov, B I, and Nairn, A E M, 1993, Permian System: Guides to geological excursions in the Uralian type localities: Occasional Publications ESRI (Earth Sciences and Resources Institute), n. ser. no. 10, 303 pp.

Chuvashov, B I, Sofronitsky, P A, Molin, V K, 1994, Permian stratigraphic scheme of the Urals, Explanation note: Ekaterinburg, pp.128-152.

Claoué Long, J C, Zhang Zi-chao, Ma Guogan and Du Shaohua, 1991, The age of Permian-Triassic boundary: Earth and Plenetary Sciences Letters, v. 105, pp. 182-190.

Davydov, V I, Barskov, I S, Bogoslovskaya, M F, Leven, E Y, Popov, A V, Akhmetshina, L Z, and Kozitskaya, R I, 1992, The Carboniferous-Permian Boundary in the former USSR and its correlation: International Geological Review, v.34, no.9: pp 889-906.

Davydov, V I, Glenister, B F, Spinosa, C, Ritter, S M, Chernykh, V V, Wardlaw, B R, and Snyder, W S, 1995, Proposal of Aidaralash as GSSP for the base of the Permian System: Permophiles, no. 26, pp. 1-9.

Dunbar, C O, 1940, The type Permian-its classification and correlation: American Association of Petroleum Geologists Bulletin, v. 24, no. 2, pp. 237-281.

Furnish, W M, 1973, Permian Stage names, in Logan, A., and Hills, L. V., eds., The Permian and Triassic systems and their mutual boundary: Canadian Society of Petroleum Geologists Memoir 2, pp. 522-549.

Glenister, B F, and Furnish, W M, 1961, The Permian Ammonoids of Australia: Journal of Paleontology, v. 35, pp. 673-736.

Glenister, B F, Boyd, D W, Furnish, W M, Grant, R E, Harris, M T, Kozur, H, Lambert, L L, Nassichuk, W W, Newell, N D., Pray, L C, Spinosa, C, Wardlaw, B R, Wilde, G L, and Yancy, T E, 1992, The Guadalupian: Proposed international standard for a Middle Permian Series: International Geology Review, v. 34, no. 9, pp. 857-888.

Gerasimov, L P, 1937, The Uralian Series of the Permian System: Scientific reports of Kazan University, vol. 97, no. 3-4, <Geology>, fasc. 8-9, 68 pp.

Griesbach, C L, 1880, Palaeontological notes on the Lower Trias of the Himalayas: Geological Survey of India, Rec., v. 13, pp. 994-1112.

Haag, M \& Heller, F, 1991, Late Permian to Early Triassic magnetostratigraphy: Earth Planet. Sci. Letter, no. 107, pp. 42-54.

Harland, W B, Armstrong, R L, Cox, A V, Craig, L E, Smith, A G, and Smith, D G, 1990, A geological time scale 1989: Cambridge University Press, $263 \mathrm{pp}$.

Heller, F., Chen, H H, Dobson, J, and Haag, M, 1995, Permian-Triassic magnetostratigraphy — new results from South China: Phys. Earth Planet. Int., no.89, pp. 281-295.

Huang, T K, 1932, The Permian formations of Southern China: Memoirs of the Geological Survey of China, Ser. A, no. 10, pp. 1-40.
Iranian-Chinese Research Group, 1995, Field work on the Lopingian stratigraphy in Iran: Permophiles, no. 27, pp. 5-6.

Jin Yu-gan, Mei Shi-long and Zhu Zhi-li, 1993, The potential stratigraphic levels of GuadalupianLopingian boundary: Permophiles no. 23, pp. 17 20.

Jin Yu-gan. Glenister, B F, Kotlyar, G V, and Sheng Jin-zhang, 1994a, An Operational Scheme of Permian Chronostratigraphy: in Jin Yu-gan, Utting, J, and Wardlaw, B R, eds., Permian Stratigraphy, Environments and Resources: Palaeoworld, v.4, p.1-14.

Jin Yu-gan, Sheng Jin-zhang, Glenister, B F, Furnish, W M, Kotlyar, G V, Wardlaw, B R, Kozur, H, Ross, C R, and Spinosa, C, 1994b, Revised operational scheme of Permian chronostratigraphy: Permophiles, no.25, pp.12-14.

Jin Yu-gan, Mei Shi-long \& Zhu Zili, 1994c, The Maokouan-Lopingian boundary sequences in South China, in Jin Yu-gan, Utting, J, and Wardlaw, B R, eds., Permian Stratigraphy, Environments and Resources: Palaeoworld, v.4, pp. 119-132.

Jin Yu-gan, 1996, A global chronostratigraphic scheme for the Permian System: Permophiles no. 28, pp. 4-10.

Karpinsky, A P, 1874, Geological Studies in the Orenburgian Region: Il Zapiski Imper. (St. Petersburg), Minearalog., Obsch., ser. 2, pt. 9, 101 pp.

Kotlyar, G V and Stepanov, D L, eds., 1984, Main features of the stratigraphy of the Permian System in U.S.S.R.: VSEGEI n. ser. 286, <Nedra>, Leningrad, $233 \mathrm{pp}$.

Kotlyar G V and Pronina, G P, 1995, Murgabian and Midian Stages of the Tethyan Realm: Permophiles, no.27, p.23-26.

Kozur, H, 1977, Beitrage zur Stratigraphie des Perm, Teil I: Probleme der Abgrenzung und Gliederung des Perm: Freiberger Forschhungshefte, no. 319 ,pp. $79-121$.

Lambert, L L, and Wardlaw, B R, 1996, Precise boundary definitions for the Guadalupian Subseries and its component stages: analyzing the conodont transitional morphoclines, in Wardlaw, B R, and Rohr, D M, eds., Abstracts and Proceedings of the Second International Guadalupian Symposium: Alpine, Texas, Sul Ross State University, pp. 40-60.

Lapparent, A de, 1900, Traite de Geologie: fasc. 2, Paris, pp. 591-1237.

Leven, E Ya, Bogoslovskaya, M F, Ganelin, V G, Grunt., T A, Leonova, T B, and Reimers, A N, 1996, Reorganization of marine biota during the MidEarly Permian Epoch: Stratigraphy and Geological Correlation v.4, no.1, pp. 57-66.

Li Hua-mei and Wang Jun-da, 1989, Magnetostratigraphy of Permo-Triassic boundary section of Meishan of Changxing, Zhejiang: Science in China, v. B, no. 6 , pp. $652-658$.

Likharew, B K, ed., 1966, The Stratigraphy of U.S.S.R.: The Permian System, <Nedra>, Moscow, 536pp

Mei Shi-long, Jin Yu-gan and Wardlaw, B. R., 1994a, Succession of conodont zones from the Permian "Kuhfeng Formation", Xuanhan. Sichuan and its implications in global correlation: Acta Palaeontologica Sinica, v. 33 , no. 1, pp.1-23.

Mei Shi-long, Jin Yu-gan and Wardlaw, B R, 1994b, Succession of Wuchiapingian conodonts from northeastern Sichuan and its worldwide correlation: Acta Micropalaeontologica Sinica, no.11 (2), pp.121-139.

Mei Shi-long, Jin Yu-gan, and Wardlaw, B R, 1994c, Zonation of conodonts from the Maokouan-Lopingian boundary strata South China. in Jin Yugan, Utting, J, and Wardlaw, B R, eds., Permian Stratigraphy, Environments and Resources: Palaeoworld, v.4, pp. 225-233.

Menning, M A, 1993, A revised Permian polarity time scale: EUG VII Abstr., Strasbourg, April 4-8.

Menning, M A, 1995, Numerical Time Scale for the Permian and Triassic Periods. An integrated Time Analysis, in Scholle, P A, Peryt, T M, and Ulmer-Scholle, D S, eds., Permian of the Northern Pangea. 1: SpringerVerlag, Berlin, pp. 77-97.

Minato, M, Kato, M, Nakamura, K, Hasegawa, Y, Choi, D R, and Tazawa, J, 1978, Biostratigraphy and correlation of the Permian in Japan: Journ. Fac. Sci., Hakkaido Univ, ser. 4, v.18, no.1-2, pp. 11-47.

Murchison, R I, 1841, Letter to Dr. Fisher v. Waldheim: Philosophical Magazine, n. s., v. 19,418 pp.

Nassichuk, W W, 1995, Permian Ammonoids in the Arctic Regions of the world, in Scholle, P A, Peryt, T M, and Ulmer-scholle, D S, eds., Permian of the Northern Pangea. 1: Springer-Verlag, Berlin, pp. 210-236.

Odin, G S, and Odin, C, 1990, Echelle numerique des temps geologiques: Geochronique no. 35, pp. 12-21.

Reno, P R, Zhang Zichao, Richard. M A, Black, M T, and Basu, A R, 1995, Synchrony and causal relations between Permian-Triassic boundary crises and Siberian flood volcanism: Science, no. 269, pp.1413-1416.

Roberts, J, ClaouĖ-Long, J C and Foster C B, 1996, SHRIMP zircon dating of the Permian System of eastern Australia: Australian J. Earth Sci., no. 43, pp. 401-421. 
Ross, C A, and Ross, J R P, 1987, Late Paleozoic sea levels and depositional sequences, in Ross, C A, and Haman, D, eds., Timing and depositional history of eustatic sequences, Constraints on seismic stratigraphy: Cushman Foundation for Foraminiferal Research, Special Publication, no. 24, pp. 137-149.

Ruzhencev, V E, 1936, New data on the stratigraphy of the Carboniferous and Lower Permian of the Orenburg and Aktiubinsk Districts: Problems of Soviet Geology, no. 6, pp. 470-506.

Ruzhencev, V E, 1950, Upper Carboniferous Ammonoids of the Urals: Trudy Paleontologicheskogo Instituta, v. 29, 223 pp.

Ruzhencev, V E, 1951, Lower Permian Ammonoids of the Southern Urals: I, Ammonoids of the Sakmarian Stage: Trudy Paleontologicheskogo Instituta, v. 33, 186 pp.

Stepanov, D L. 1973. The Permian System in the U.S.S.R., in Logan, A, and Hills, L V, eds., The Permian and Triassic systems and their mutual boundary: Canadian Society of Petroleum Geologists Memoir 2, pp. 120-136.

Wardlaw, B R, and Rohr, D M, 1996, Abstracts and Proceedings of the Second International Guadalupian Symposium: Alpine, Texas, Sul Ross State University, $80 \mathrm{pp}$.

Wardlaw, B R, and Mei Shi-long, in press, A discussion of the early reported species of Clarkina (Permian, Conodonta) and the possible origin of the genus: Palaeoworld.

Wardlaw, B R, and Pogue, K R, 1995, The Permian of Pakistan, in Scholle, P A. Peryt, T M, and Ulmer-Scholle, D S, eds., The Permian of Northern Pangea, Volume 2 (Sedimentary Basins and Economic Resources): Heidelberg, Springer-Verlag Publishers, pp. 215-224.

Waterhouse, J B, 1976, World correlations for marine Permian faunas: Queensland University Department of Geology Papers, v. 7, no. 2., 232 pp.

Waterhouse, J B, 1982, An early Djulfian (Permian) brachiopod faunule from Upper Shyok Valley, Karakorum Range, and the implications for dating of allied faunas from Iran and Pakistan: Contribution to Himalayas Geology, no.2: pp.188-233.

Yin Hong-fu, Yang Feng-qin, Zhang Ke-xing, and Yang Wei-ping, 1988, A proposal to the biostratigraphic criterion of Permian-Triassic boundary: Mem. Soc. Geol. Ital., no. 34: pp. 320-344.

Zhao Jin-ke, Sheng Jin-zhang, Yao Zhao-qi, Liang Xi-lou, Chen Cui-zhen, Rui Lin, and Liao Zhuo-ting, 1981, The Changhsingian and Permian-Triassic boundary of South China: Bulletin of the Nanjing Institute of Geology and Palaeontology, Academia Sinica no. 2, pp. 1-112.

Zhou Zu-ren, 1987, Early Permian Ammonite-Fauna from Southeastern Hunan: Papers Collection of post-graduates in Nanjing Institute of Geology and Palaeontology, Academia Sinica, no.1: Jiangsu Science and Technology Publishing House, Nanjing, pp. 343-398.

Zhu Zi-li and Zhang Lin-xin, 1994, On the Chihsian Successions in South China, in Jin Yu-gan, Utting, J, and Wardlaw, B R, eds., Permian Stratigraphy, Environments and Resources: Palaeoworld v.4, pp.114-138.
Professor Jin Yu-gan is Director of the Open Laboratory of Palaeobiology and Stratigraphy in Nanjing Institute of Geology and Palaeontology. His research is concentrated on the Carboniferous and Permian stratigraphy and the Late Palaeozoic and Mesozoic brachiopods. He has served as the Secretary (19841989) and Chairman (1989-1996) of the Subcommission on Permian Stratigraphy.

Dr. Bruce R. Wardlaw is Chief Palaeontologist of U. S. Geological Survey. His current interests include Permian conodonts and stratigraphy, coal geology in Pakistan, and coastal environmental geology. He is currently Chairman of the Subcommission on Permian Stratigraphy.

Professor Brian F. Glenister is Professor of Palaeontology at Department of Geology, University of Iowa. His research concentrates on Permian ammonoid taxonomy and biostratigraphy. He is past Chairman (1981-1984) of the International Subcommission on Permian Stratigraphy.

Dr. Galina V. Kotlyar is Leading Scientist of the Department of Palaeontology and Stratigraphy in All Russian Geological Research Institute (VSEGEI) at St. Petersburg. Her research is mainly concentrated on the Carboniferous and Permian brachiopods and stratigraphy. She is a Titular Member of International Subcommission on Permian Stratigraphy.
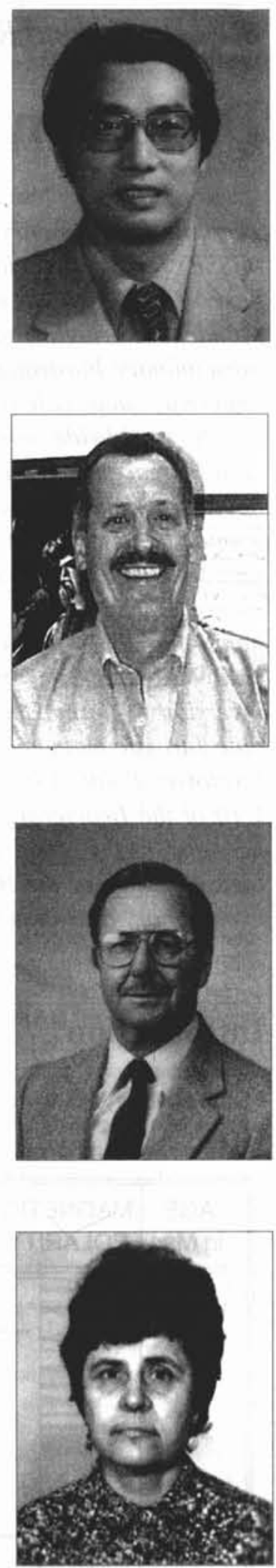